\title{
The Analysis Of Voltage Optimization System With Pararel Series Arranger In Solar Cell
}

\author{
M. Ibrahim Ashari ${ }^{\mathrm{a}, 1, *}$, Ahmad Faisol ${ }^{\mathrm{b}, 2}$ \\ a Department of Electrical Engineering Faculty of Industrial Technology, ITN Malang, J1. Sigura - Gura No.2, Sumbersari, \\ Kec. Lowokwaru, Malang and 65152, Indonesia \\ b Department of Electrical Engineering Faculty of Industrial Technology, ITN Malang, Jl. Sigura - Gura No.2, Sumbersari, \\ Kec. Lowokwaru, Malang and 65152, Indonesia \\ ${ }^{1}$ ibrahim_ashari@lecturer.itn.ac.id*; ${ }^{2}$ mzfaiz@gmail.com
}

\begin{tabular}{|c|c|}
\hline & ABSTRACT \\
\hline $\begin{array}{l}\text { Keywords } \\
\text { Solar Cell } \\
\text { Charger Controller } \\
\text { Battery }\end{array}$ & $\begin{array}{l}\text { Parallel series is very suitable to be used to overcome the ups and down of voltage caused } \\
\text { by the supply of sunlight to the solar cell. The series circuit can be used to overcome the } \\
\text { lack of voltage on the solar cell, while the parallel circuit is used to flow larger currents } \\
\text { with a constant voltage when the supply of sunlight on the solar cell is at its maximum. } \\
\text { Solar cell as converters of sunlight into electrical energy in the form of DC voltages, which } \\
\text { are connected in parallel series by utilizing relay contacts that are controlled using atmega } \\
16 \text { microcontroller, where the voltage generated by the solar cell in the sensor uses a } \\
\text { voltage sensor. Switching regulator as lowering the voltage over solar cell for battery } \\
\text { charging. The test results using a series of series and minimum lighting produces a voltage } \\
14,8 \text { Volt, parallel circuits and maximum lighting produces a voltage of } 20 \text { volts, and a } \\
\text { combination of parallel-series under moderate lighting conditions produces a voltage of } \\
23.3 \text { Volt. }\end{array}$ \\
\hline
\end{tabular}

\section{Introduction}

Electrical energy is a very important requirement in the life of humanity. Solar energy is one alternative that is widely used because it is very promising, among others in terms of abundance in nature, clean, safe and possible as an energy generator in remote areas. Solar cell are now widely used in the environment, because in addition to being environmentally and cannot be used up.

Currently the researchers are looking for solutions on how to optimize the voltage for charging the battery, so that in the morning at precisely 6:00 the battery is working. But in fact the battery cannot work at that hour, because the sunlight conditions are still not bright and the voltage generated by the solar cell is very minimal to meet battery charging. The researcher used "automatic reconfiguration of series and parallel circuits to connect 1 solar cell modules so as to produce the optimal voltage and current for battery charging"[1][2]. In theory, if the battery circuit is connected in series then what happens in the voltage will be large and the current remains the same, while the battery circuit is connected in parallel then what happens is the same voltage and large current.[3]

Parallel series is very suitable to be used to overcome the ups and downs of the voltage caused by the supply of sunlight to solar cells.

Referring to these problems, the problem of this research can be formulated as follows:

1. How to make a series that can automatically arrange parallel series on 4 solar cells?

2. How to optimize voltage with series, parallel and series-parallel circuits?

The purpose of this research is to design and create a series to automatically regulate parallel series on 4 solar cells and create voltage optimization system with series, parallel and series-parallel circuits. 


\section{The Proposed Method/Algorithm}

\subsection{Solar Cell}

A solar cell is a device that converts sunlight energy into electrical energy by the process of the photovoltaic effect, hence it is also called a photovoltaic cell (abbreviated as PV). The voltage generated by a solar cell is very small, around $0.6 \mathrm{~V}$ without load or $0.45 \mathrm{~V}$ with load. To get a large electric voltage as you wish, several solar cells are arranged in series. If 36 pieces of cells from PLN such as street vendors, people who live in remote areas and areas that have not been electrified from PLN. Another source of electrical energy that can be utilized by the public electric energy sources other than from PLN is a generator or more commonly called a generator set.[4]

Efficient use of each alternative electrical energy source needs to be known so that in its use we get maximum results.

Solar cells arranged in series, will produce a voltage of around $16 \mathrm{~V}$. This voltage is enough to be used to supply $12 \mathrm{~V}$ batteries. To get a bigger output voltage, more solar cells are needed. This combination of colar cells is caled a Solar Panel or solar module. Arrangements of about 10-20 of more Solar Panels will be able to produce currents and high voltages sufficient for daily needs [5].

\subsection{Series and Parallel}

Basically, batteries can be arranged in series or parallel. But the output from the two circuits will be different. The Battery Series circuit will increase the Battery Output Voltage while the Electric Current will remain the same[1]. This is in contrast to the Parallel Circuit Battery which will increase the Lectric Current but the output voltage will remain the same [6].

\section{Method}

\subsection{Block of Entire System Diagram}

Block diagram of the whole system which generally consists of inputs and outputs processed by a microcontroller.

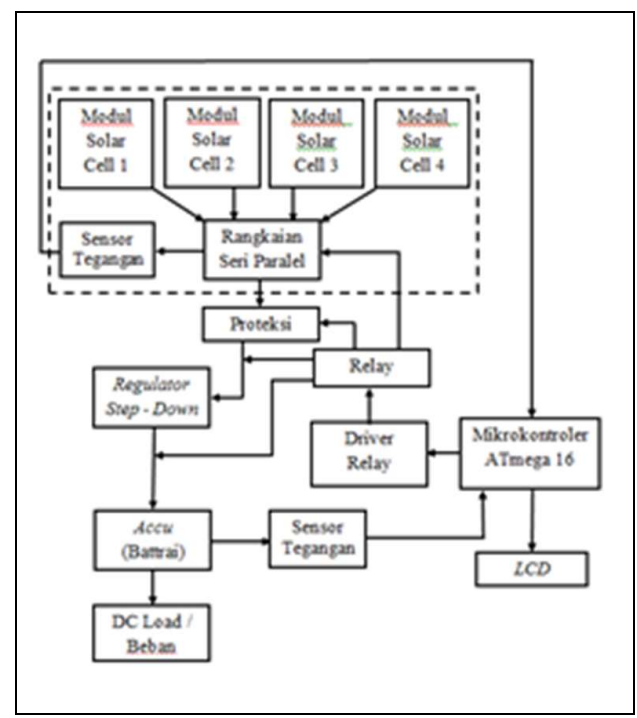

Fig. 1. Block of Entire System Diagram Tools Ways to Work

From the block diagram, it can be explained how this tool works, namely there are 4 solar cells as converting sunlight into electrical energy in the form of DC voltage and which will be controlled using a series of parallel series in order to get more optimal voltage. The parallel series circuit control is controlled using microcontroller and relay as a switcher. The microcontroller works based on the output of the voltage sensor which censors the output voltage of the parallel series in circuit. The microcontroller commands the relay by using $\mathrm{NC}$ and $\mathrm{NO}$ to change the circuit in series, parallel, and series-parallel conditions. When the output voltage in series, parallel, and parallel series exceeds $39 \mathrm{~V}$ 
rhe relay is active protection[7]. The result of the voltage in series, parallel, and parallel-series stored in the battery, the battery needs a voltage of $13,8 \mathrm{~V}$ to work. For voltages that exceed a voltage value of $13.8 \mathrm{~V}$ are derived using a s regulator step-down. In addition, the microcontroller also controls battery charging and the battery charging breaker (cut off). The microcontroller also commands the LCD to display the value of the volatge produced by the output in series, parallel and parallelseries.the voltage from the results of battery storage (Accu) is released into the dc load equipment.

\section{Results and Discussion}

\subsection{Series Testing}

\subsubsection{The Purpose}

This test is carried out to find out whether the circuit runs according to the design or not and to know whether the series is in accordance with the calculation or not. This can be done by using DPDT relay to contact the switch in the condition of a series-parallel circuit.

\subsubsection{Testing Result an Testing Analysis}

From the results it is known that measurements in the series circuit get measurement data using solar cell output voltage. Table 1 shows that the series testing conditions in accordance with the design series.

Table 1. Series Condition Test Result

\begin{tabular}{cccccccc}
\hline No. & $\begin{array}{c}\text { Solar } \\
\text { Cell 1 } \\
(\boldsymbol{V})\end{array}$ & $\begin{array}{c}\text { Solar } \\
\text { Cell 2 } \\
(\boldsymbol{V})\end{array}$ & $\begin{array}{c}\text { Solar } \\
\text { Cell 3 } \\
(\boldsymbol{V})\end{array}$ & $\begin{array}{c}\text { Solar } \\
\text { Cell 4 } \\
(\boldsymbol{V})\end{array}$ & $\begin{array}{c}\text { Measurement } \\
(\boldsymbol{V})\end{array}$ & $\begin{array}{c}\text { Calculation } \\
(\boldsymbol{V})\end{array}$ & Error\% \\
\hline 1. & 16.6 & 17.4 & 13.8 & 17.3 & 65.2 & 65.1 & 0.1 \\
2. & 16.4 & 17.3 & 13.7 & 17.1 & 64.6 & 64.5 & 0.1 \\
3. & 16.4 & 17.2 & 13.7 & 17.1 & 64.3 & 64.3 & 0 \\
4. & 16.3 & 17.2 & 13.6 & 17.0 & 64.3 & 64 & 0.3 \\
5. & 16.2 & 17.2 & 13.6 & 16.9 & 63.7 & 63.7 & 0 \\
\hline
\end{tabular}

The results of the solar cell output voltage can also be calculated by calculating the series battery conditions.

$$
\begin{aligned}
V_{t o t} & =V_{S C 1}+V_{S C 2}+V_{S C 3}+V_{S C 4} \\
& =16,6+17,4+13,8+17,3 \\
& =65,1 \mathrm{~V}
\end{aligned}
$$

Calculation of the value of the series voltage conditions can be found by the equation:

$$
\begin{aligned}
\% \text { Error } & =\frac{\mid \text { Calculation-Measurement } \mid}{\text { Measurement }} \times 100 \% . \\
& =\frac{|65,1-65,2|}{65,2} \times 1001 \% \\
& =\frac{|0,1|}{65,2} \times 100 \% \\
& =0,001 \times 100 \% \\
& =0,1 \%
\end{aligned}
$$

So we get an average percent error:S

$$
\begin{aligned}
\% \text { Error Average } & =\frac{\text { Total number } \%}{\text { Number of Tests }} . \\
& =\frac{0,5 \%}{5}
\end{aligned}
$$




$$
=0,1 \%
$$

From the results of testing the series condition relay circuit, an average error of $0.1 \%$ is obtained.

\subsection{Parallel Circuit Testing}

\subsubsection{The Purpose}

This test is done to find out whether the circuit runs according to the design or not and to find out whether the parallel circuit is in accordance with the calculation or not. This can be done by using a DPDT relay to contact the switch in parallel circuit conditions.

\subsubsection{Testing Results and Testing Analysis}

From the test result it is known that measurements $n$ parallel circuits get measurement data using solar cell output voltage. In table 2 it shows that the testing of parallel conditions in accordance with the design.

Table 2. Result of Paraller Circuit Testing

\begin{tabular}{cccccccc}
\hline No. & $\begin{array}{c}\text { Solar } \\
\text { Cell 1 } \\
(\boldsymbol{V})\end{array}$ & $\begin{array}{c}\text { Solar } \\
\text { Cell 2 } \\
(\boldsymbol{V})\end{array}$ & $\begin{array}{c}\text { Solar } \\
\text { Cell 3 } \\
(\boldsymbol{V})\end{array}$ & $\begin{array}{c}\text { Solar } \\
\text { Cell 4 } \\
(\boldsymbol{V})\end{array}$ & $\begin{array}{c}\text { Measurement } \\
(\boldsymbol{V})\end{array}$ & $\begin{array}{c}\text { Calculation } \\
(\boldsymbol{V})\end{array}$ & Eror\% \\
\hline 1. & 16.6 & 17.5 & 17.4 & 17.4 & 17.4 & 17.2 & 0.1 \\
2. & 16.5 & 17.3 & 17.3 & 17.3 & 17.3 & 17.1 & 0.1 \\
3. & 16.3 & 17.2 & 17.2 & 17.2 & 17.2 & 16.9 & 0.1 \\
4. & 16.2 & 17.2 & 17.1 & 17.1 & 17.1 & 16.9 & 0.1 \\
5. & 16.3 & 17.1 & 17.1 & 17.1 & 17.1 & 16,9 & 0.1 \\
\hline
\end{tabular}

The result of the solar cell output voltage can also be calculated by calculating the parallel condition of the battery circuit.

$$
\begin{aligned}
V_{t o t} & =\frac{V_{S C 1}+V_{S C 2}+V_{S C 3}+V_{S C 4}}{4} \\
& =\frac{16,6+17,5+17,4+17,4}{4} \\
& =\frac{68,9}{4} \\
& =17,2 \mathrm{~V}
\end{aligned}
$$

Calculation of the value of the parallel condition voltage can be searched by equation,

$$
\begin{aligned}
\% \text { Error } & =\frac{\mid \text { Calculation }- \text { Measurement } \mid}{\text { Measurement }} \times 100 \% \\
& =\frac{|17,2-17,4|}{17,4} \times 1001 \% \\
& =\frac{|0,2|}{17,4} \times 100 \% \\
& =0,001 \times 100 \% \\
& =0,1 \%
\end{aligned}
$$

So it get an average percent error:

$$
\begin{aligned}
\% \text { Error Average } & =\frac{\text { Total number } \%}{\text { Measurement }} \\
& =\frac{0,5 \%}{5} \\
& =0,1 \%
\end{aligned}
$$


JEEMECS (Journal of Electrical Engineering, Mechatronic and Computer Science) ISSN 2614-4859 Vol. 3, No. 2, August 2020, pp. 179-186

doil https://doi.org/10.26905/jeemecs.v3i2.4731

From the results of testing the parallel condition relay circuit above, an average error of $0.1 \%$ is obtained.

\subsection{Testing Overall Tools}

\subsubsection{The Purpose}

The purpose of this whole system test is to determine whether parallel series settings function according to the design results.

\subsubsection{Testing Results and Testing Analysis}

After testing each series block, the next is to test the whole system. This test is done by combining all series block into one, so the system can be tested completely. This overall test uses a simulation of solar lighting by using objects as solar cell cover to determine the voltage in series, parallel and parallel-series conditions.

Table 3. Maximum Test Result for Maximum Lighting Condisions

\begin{tabular}{cccccc}
\hline \multirow{2}{*}{ No } & \multirow{2}{*}{ Irradiance conditions } & \multirow{2}{*}{ Conditions } & $\begin{array}{c}\text { Measuring voltmeter } \\
(\boldsymbol{V})\end{array}$ & $\begin{array}{c}\text { Voltage sensor } \\
(\boldsymbol{V})\end{array}$ & \multirow{2}{*}{ Eror \% } \\
\hline 1 & Maximum & Parallel & 20.4 & 20.4 & 0 \\
2 & Maximum & Series-parallel & 38.2 & 38.0 & 0.5 \\
3 & Maximum & Series & 74.1 & 74.3 & 0.2 \\
\hline
\end{tabular}

Calculation of the voltage value of the series, parallel, and serial-parallel conditions can be found by the equation,

$$
\begin{aligned}
\% \text { Error } & =\frac{\mid \text { Voltage Sensor Measurement }- \text { Voltmeter Measurement } \mid}{\text { Voltage Sensor Measurement }} \times 100 \% \\
& =\frac{|74,3-74,1|}{74,1} \times 1001 \% \\
& =\frac{|0,2|}{74,1} \times 100 \% \\
& =0,002 \times 100 \% \\
& =0,2 \%
\end{aligned}
$$

So it get an average percent error:

$$
\begin{aligned}
\% \text { Error Average } & =\frac{\text { Total number } \%}{\text { Measurement }} \\
& =\frac{0,7 \%}{3} \\
& =0,23 \%
\end{aligned}
$$

So it get an average percent error $0,23 \%$

Table 4. Overall Testing Result With Lighting Simulation

\begin{tabular}{cccc}
\hline \multirow{2}{*}{ No } & Irradiance & Conditions & $\begin{array}{c}\text { Voltage Sensor } \\
\text { Conditions }\end{array}$ \\
\hline 1 & Maksimum & Parallel & 20.0 \\
2 & Medium & Series-parallel & 23.3 \\
3 & Minimum & Series & 14.8 \\
\hline
\end{tabular}

Charging the battery takes 10,5 hours in parallel conditions with a $12 \mathrm{~V} 35 \mathrm{AH}$ capacity battery, obtained from calculations:

Note : Battery capacity $=12$ V 35 AH

Asked : Battery power $=35 \mathrm{AH}$ x $12 \mathrm{~V}=420$ watt 


$$
\begin{aligned}
\text { Charging the Battery (Hours) } & =\frac{\text { Battery Capacity }}{\text { Solar Cell Capacity }} \\
& =\frac{420}{4 \times 10 \mathrm{WP}} \\
& =10,5 \text { hours }
\end{aligned}
$$

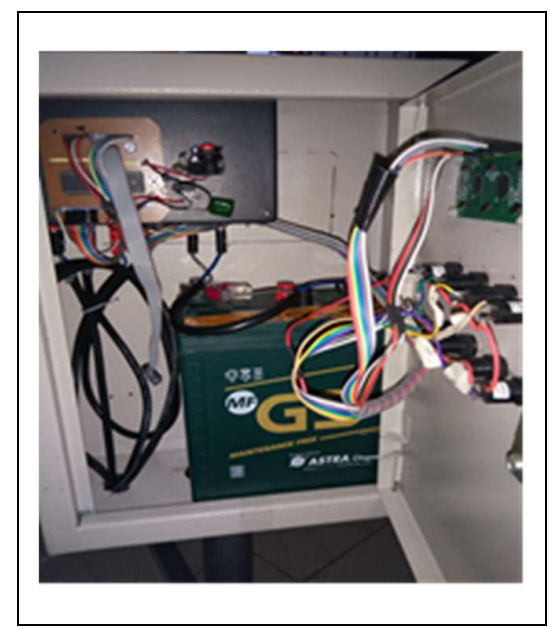

Fig. 2. Inside the Panel Box

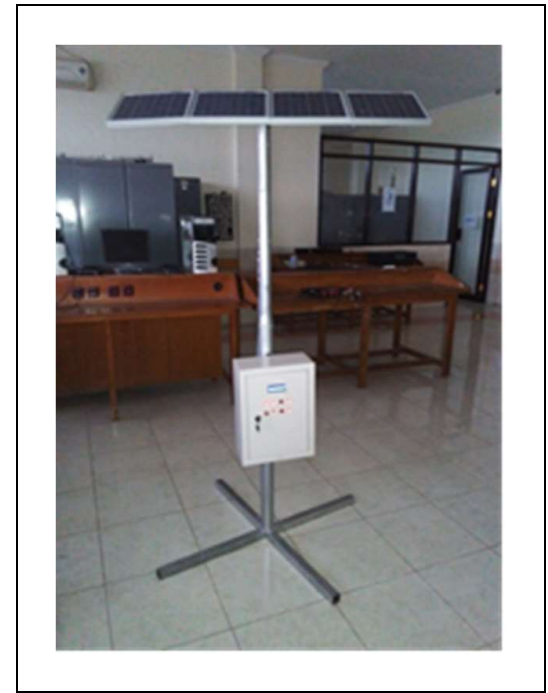

Fig. 3. Overall Tool Shape

\section{Conclusion}

After the design and manufacturing process and the testing tolos are carried out, conclusions can be drawn :

1. The results of testing the series relay circuit conditions, obtained an average error of $0.1 \%$.

2. The results of testing the parallel condition relay circuit, obtained an average error of $0.1 \%$.

3. The series, parallel, and parallel-series condition settings can change automatically according to the changing light intensity.

4. Based on solar cell testing with minimal lighting in series circuit conditios of 14.8 volts.

5. Based on solar cell testing by lighting in the conditions of a series-parallel circuit getting a voltage of 23.3 volt. 
JEEMECS (Journal of Electrical Engineering, Mechatronic and Computer Science) ISSN 2614-4859

Vol. 3, No. 2, August 2020, pp. 179-186

doi https://doi.org/10.26905/jeemecs.v3i2.4731

6. Based on solar cell testing with maximum illumination in parallel circuit conditions get a voltage of 20.0 volt.

\section{References}

[1] R. S. Putra, "Analisa Cover Sub Assy Battery untuk Kendaraan Bermotor Roda Empat," $J$. Tek. Mesin Mercu Buana, vol. 3, no. 3, pp. 19-26.

[2] I. Setiono, "Akumulator, pemakaian dan perawatannya," METANA, vol. 11, no. 01, 2015.

[3] P. D. P. Adi and R. Arifuddin, "Design Of Tsunami Detector Based Sort Message Service Using Arduino and SIM900A to GSM/GPRS Module," JEEMECS (Journal Electr. Eng. Mechatron. Comput. Sci., vol. 1, no. 1, pp. 1-4, 2018.

[4] A. I. Ramadhan, E. Diniardi, and S. H. Mukti, "Analisis desain sistem pembangkit listrik tenaga surya kapasitas $50 \mathrm{WP}$, , J. Tek., vol. 37, no. 2, pp. 59-63, 2016.

[5] B. H. Purwoto, "Efisiensi Penggunaan Panel Surya sebagai Sumber Energi Alternatif," Emit. J. Tek. Elektro, vol. 18, no. 01, pp. 10-14, 2018.

[6] K. Ramadhani and S. Akhlus, "Pengaruh Hubungan Seri-Paralel pada Rangkaian Sel Surya Pewarna Tersensitisasi (SSPT) Terhadap Efisiensi Konversi Energi Listrik," Pros. Tugas Akhir Semester Genap, Inst. Teknol. Sepuluh Nop., 2009.

[7] N. Arifin, R. S. Lubis, and M. Gapy, "Rancang Bangun Prototype Power Meter 1 Fasa Berbasis Mikrkontroller Atmega328P,” J. Karya Ilm. Tek. Elektro, vol. 4, no. 1, 2019. 
JEEMECS (Journal of Electrical Engineering, Mechatronic and Computer Science) ISSN 2614-4859 Vol. 3, No. 2, August 2020, pp. 179-186

\section{This page intentionally left blank}

